\author{
Bahman Mirhadi ${ }^{1}$, Behzad Mehdikhani ${ }^{2 *}$ \\ ${ }^{1}$ Imam Khomeini International University, Engineering, 34149 - 16818 , Qazvin, Iran \\ ${ }^{2}$ Institute of Standard and Research Industrial of Iran, Engineering, 31585-163, Karaj, Iran \\ beh_mehdikhani@yahoo.com
}

\title{
THE EFFECT OF COMPOSITIONAL CHANGES ON THE CRYSTALLISATION BEHAVIOUR AND MECHNICAL PROPERTIES OF $\mathrm{Li}_{2} \mathrm{O}-\mathrm{CaO}-\mathrm{SiO}_{2}-\mathrm{Al}_{2} \mathrm{O}_{3}$
}

\begin{abstract}
The crystallisation characteristics of glasses based on the $\mathrm{Li}_{2} \mathrm{O}-\mathrm{CaO}-\mathrm{SiO}_{2}-\mathrm{Al}_{2} \mathrm{O}_{3}(\mathrm{LCSA})$ system containing $\mathrm{TiO}_{2}$, $\mathrm{ZrO}_{2}$ has been investigated by differential thermal analysis (DTA), X-ray diffraction analysis (XRD), and scanning electron microscopy (SEM). The partial replacement of $\mathrm{Li}_{2} \mathrm{O}, \mathrm{CaO}$ and $\mathrm{SiO}_{2}$ by $\mathrm{TiO}_{2}, \mathrm{ZrO}_{2}$ in the studied glassceramics led to the development of different crystalline phase assemblages, including lithium calcium silicates, wollastonite, $\beta$-eucryptite and $\beta$-spodumene using various heat-treatment processes. The rod-like growth morphology was observed by SEM for glass free of $\mathrm{TiO}_{2}$. In this glass, $\mathrm{ZrO}_{2}$ reduced mobility of boundary at sintering temperature, $1000^{\circ} \mathrm{C}$ and relatively density was $77 \%$. The most sinterability observed in sample containing $\mathrm{TiO}_{2}$ and free of $\mathrm{ZrO}_{2}$ at sintering temperature, $1000^{\circ} \mathrm{C}$ and relatively density was $84 \%$.
\end{abstract}

Key words: $\mathrm{Li}_{2} \mathrm{O}-\mathrm{CaO}-\mathrm{SiO}_{2}-\mathrm{Al}_{2} \mathrm{O}_{3}$, crystallisation, $\mathrm{TiO}_{2}, \mathrm{ZrO}_{2}$, glass-ceramic

\section{INTRODUCTION}

Glass-ceramics are composed materials of one or more crystalline phases immersed in a residual glassy phase. They're in general outstanding properties have given rise to a wide variety of applications [1]. Glass ceramic processing has been carried out starting both from bulk glasses and from powder [2]. Glass-ceramic properties depend on microstructure and composition of phases developed during the manufacturing process. Glass-ceramics are crystalline materials formed through the controlled crystallisation of glass during specific heat treatment[3]. Mechanical properties of the ceramic materials can be improved due the incorporation of a second phase, as fibrous, hard particles or whiskers [4-7]. Several works published in the literature report the improvement in properties of glass-ceramic materials [5-9]. Aspects such as microstructure, fracture strength and fracture toughness have been extensively investigated[1012]. Lithium calcium aluminum silicate (LCAS) glass-ceramics have been extensively studied and commercialized due to the wide range of useful properties such as low or even zero thermal expansion coefficient (TEC), creep resistance, good resistance to mechanical and thermal shock, and excellent chemical durability [13-16]. In a critical review of structure, properties and 
application of glass-ceramics by Beall and Duke [17], $\mathrm{TiO}_{2}$ and $\mathrm{ZrO}_{2}$ have been separately recognized as the nucleating agents in the fabrication of $\mathrm{Li}_{2} \mathrm{O}-\mathrm{Al}_{2} \mathrm{O}_{3}-\mathrm{SiO}_{2}$ (LAS) glass-ceramics by conventional melting and crystallisation. In this work a glass ceramic material belonging to the $\mathrm{Li}_{2} \mathrm{O}-\mathrm{CaO}-\mathrm{SiO}_{2}-\mathrm{Al}_{2} \mathrm{O}_{3}$ (LCSA) system crystallised with titanium and zirconium oxide particles was investigated. The effect of the crystalline agents on the physical and mechanical properties was studied. The objective of this study is to verify the possibility to obtain a glass ceramic composite material by conventional sintering process and to investigate the potential use of titanium or zirconium oxides as crystalline agents in a LCSA matrix for improving mechanical properties. The bulk chemical composition, nucleant added, final phase assemblage and microstructure are the most important factors affecting their technical properties.

\section{EXPERIMENTAL PROCEDURE}

\section{Batch composition and glass preparation}

The glass compositions in the mol \% are given in Table 1 . The glass batches were prepared from reagent grade powders: calcium carbonate $\left(\mathrm{CaCO}_{3}\right)$, lithium carbonate $\left(\mathrm{Li}_{2} \mathrm{CO}_{3}\right)$, zirconium silicate $\left(\mathrm{ZrSiO}_{4}\right)$, quartz $\left(\mathrm{SiO}_{2}\right)$ and titanium oxide $\left(\mathrm{TiO}_{2}\right)$. The components of the batch after being accurately weighed were thoroughly mixed in agate mortar for about 15 min to ensure complete homogeneity. The weighed batches were melted in an electrically heated furnace within alumina crucible, following the same heating cycle: from 20 to $500^{\circ} \mathrm{C}$ at $5^{\circ} \mathrm{C} / \mathrm{min}$, from $500^{\circ} \mathrm{C}$ to $1500^{\circ} \mathrm{C}$ at $10^{\circ} \mathrm{C} / \mathrm{min}$ and finally $30 \mathrm{~min}$ of soaking time at the maximum temperature of $1500^{\circ} \mathrm{C}$. Melted glasses were poured into cold water and, after grinding they were remelted again. After the second melting a portion of the melt was poured into water to obtain frit and milled up frit to obtain a powder glass with particle size smaller than $30 \mu \mathrm{m}$. The sinterability of the glasses was investigated by sintering them for $240 \mathrm{~min}$ at the 800,900 and 1000 and $1100^{\circ} \mathrm{C}$ with a heating rate of $20^{\circ} \mathrm{Cmin}^{-1}$ in an electric furnace.

Table 1. Chemical compositions of glass ceramics (in mol\%)

\begin{tabular}{lllllll}
\hline Samples & $\mathrm{SiO}_{2}$ & $\mathrm{Li}_{2} \mathrm{O}$ & $\mathrm{CaO}$ & $\mathrm{TiO}_{2}$ & $\mathrm{ZrO}_{2}$ & $\mathrm{Al}_{2} \mathrm{O}_{3}$ \\
\hline $\mathrm{G} 1$ & 62.40 & 12 & 14.40 & 0 & 4 & 7.2 \\
$\mathrm{G} 2$ & 61.10 & 11.6 & 14.10 & 2 & 4 & 7.2 \\
$\mathrm{G} 3$ & 59.80 & 11.2 & 13.80 & 4 & 4 & 7.2 \\
$\mathrm{G} 4$ & 63.70 & 12.40 & 14.70 & 2 & 0 & 7.2 \\
$\mathrm{G} 5$ & 62.40 & 12 & 14.40 & 4 & 0 & 7.2 \\
\hline
\end{tabular}

\section{Thermal measurements}

The thermal behavior of glasses was monitored by DTA scans which were carried out using a simultaneous thermal analyzer (STA-1640). Platinum containers were used for both the glass and the reference samples in air static atmosphere. The DTA equipment was calibrated periodically using $\mathrm{Na}_{2} \mathrm{SO}_{4}$ as a standard at the same conditions used for the samples measurements. The data were recorded and analysed in a computer interfaced with the DTA equipment. 


\section{X-ray diffraction (XRD) and Density}

Identification of the crystal phases precipitating due to the course of crystallisation was conducted by X-ray diffraction analysis (XRD) of the powdered samples. In order to determine the crystallisation products, the heat-treated samples were subjected to XRD analysis (Siemens, $\mathrm{D}-500$ ) using $\mathrm{Cu} \mathrm{K} \alpha$ radiation at $40 \mathrm{kV}$ and $20 \mathrm{~mA}$ setting and in $2 \theta$ range from $5 \circ$ to $70^{\circ}$. The crystallisation characteristics and internal microstructures of fractured surfaces of the crystalline samples, coated with gold spray, were examined by using scanning electron microscopy (SEM model VEGA-TESCAN), on superficially polished gold-coated specimens. Energy dispersion Xray spectroscopy, EDS, was used to identify the chemical composition of the different phases in the samples. The bulk density of the sintered glass-ceramics was determined by the Archimedes method.

\section{Mechanical tests}

For bending strength tests, rectangular bars with dimensions of $10 \mathrm{~mm} \times 5 \mathrm{~mm} \times 40 \mathrm{~mm}$ were cold-pressed. Bending strength values were determined by three point loading method, using an uniaxially pressed testing machine. The glass powders were mixed with $7 \mathrm{wt} . \%$ methyl cellulose and cold-pressed at pressure of $65 \mathrm{MPa}$.

\section{RESULT AND DISCUSSION}

\section{Thermal analysis}

The DTA curves of the G1-G5 glasses are shown in Fig.1. Various endothermic and exothermic effects in the $750-850^{\circ} \mathrm{C}$ temperature range, which referred to the glass transition $\mathrm{T}_{\mathrm{g}}(\mathrm{C})$ and crystallisation peak $\mathrm{T}_{\mathrm{c}}(\mathrm{C})$ of the glasses, are also recorded, their first crystallisation peak temperatures have been summarised in Table 2 .

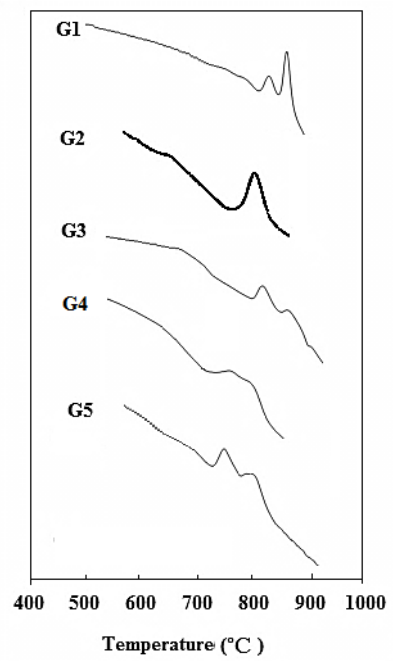

Fig.1. DTA curves of samples, G1-G5 
Table 2. The first crystallisation peak temperatures of glasses

\begin{tabular}{lll}
\hline Glass & $\mathrm{T}_{\mathrm{g}}(\mathrm{C})$ & $\mathrm{T}_{\mathrm{C}}(\mathrm{C})$ \\
\hline $\mathrm{G} 1$ & 805 & 850 \\
$\mathrm{G} 2$ & 750 & 810 \\
$\mathrm{G} 3$ & 760 & 815 \\
$\mathrm{G} 4$ & 705 & 760 \\
$\mathrm{G} 5$ & 710 & 750 \\
\hline
\end{tabular}

Sample G1 was chosen to illustrate the typical thermal behavior of the investigated glass materials, which is shown in Fig.1. According to the DTA curve an exothermic peak that occur at $850^{\circ} \mathrm{C}$ is characteristic of the glass crystallisation. It can then be elucidated that the gradual addition of $\mathrm{TiO}_{2}$ to glasses, shifts the crystallisation peak to lower temperature. The comparison of glass transition temperatures (Tg) (Table 2) again confirms the process of viscosity reduction due to the addition of $\mathrm{TiO}_{2}$ additive. It can be seen that the simultaneous addition of $4.0 \% \mathrm{~mol} \mathrm{TiO}_{2}$ causes a nearly $45^{\circ} \mathrm{C}$ reduction in $\mathrm{Tg}$, for glasses containing $\mathrm{ZrO}_{2}$. This partly is due to the role of $\mathrm{TiO} 2$ which probably as network modifiers assumes a co-ordination number of six cations in these glasses in the range of glass transform temperatures [18]. Ionic radius of $\mathrm{Ti}^{4+}$ is larger than $\mathrm{Si}^{4+}$ it prefers octahedral or cubic co-ordination at lower temperatures $($ at $\mathrm{T}<\mathrm{Tg}$ ) of glasses. $\mathrm{Ti}^{4+}$ ion, which was four-fold co-ordinated at higher temperatures (at $\mathrm{T}>\mathrm{Tg}$ ) in some glasses containing relatively lower amounts of $\mathrm{RO}$ (alkaline earth) oxides gradually becomes six-fold co-ordinated as nucleation occurred. Therefore, $\mathrm{TiO}_{2}$ resulted in crystallisation in such glasses. On the other hand in glasses with relatively large amounts of alkali and or alkaline earth oxides owing to the existence of a large number of non-bridging oxygen ions, $\mathrm{Ti}^{4+}$ cations can attain a co-ordination number of 6 and coordination change does not occur in them during heat treatment[19]. Figs. 2, 3 depict the variation of linear shrinkage of compacted glass powder and relative density with firing temperature.

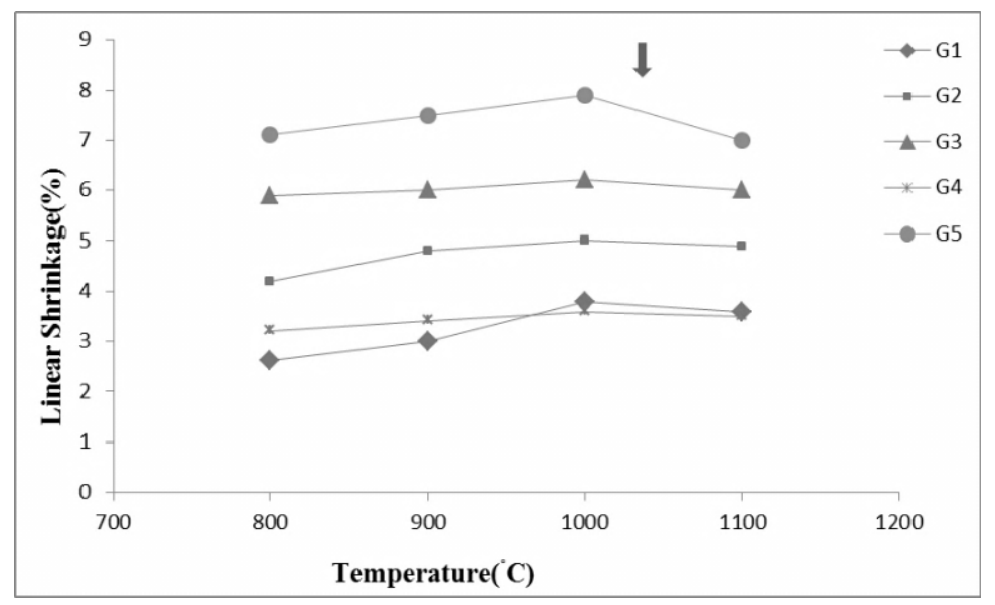

Fig. 2. Variation of linear shrinkage of glasses with firing temperature

Addition of $\mathrm{TiO}_{2}$ up to $4.0 \% \mathrm{~mol}$, as respected, leads to improving of sinterability, may be due to increasing of viscous flow of glass. It seems that reduction of the linear shrinkage after $1000^{\circ} \mathrm{C}$ is somewhat related to the bloating of the glass-ceramic (G1). It can be noted that the increase of the sintering temperature from $1000^{\circ} \mathrm{C}$ to $1100^{\circ} \mathrm{C}$ reduces the linear shrinkage samples, which is 
probably related to the volatility of this glass ceramics at high temperatures. This behavior indicates that temperature of nucleation ability of crystalline phases improve by addition of $\mathrm{TiO}_{2}$.

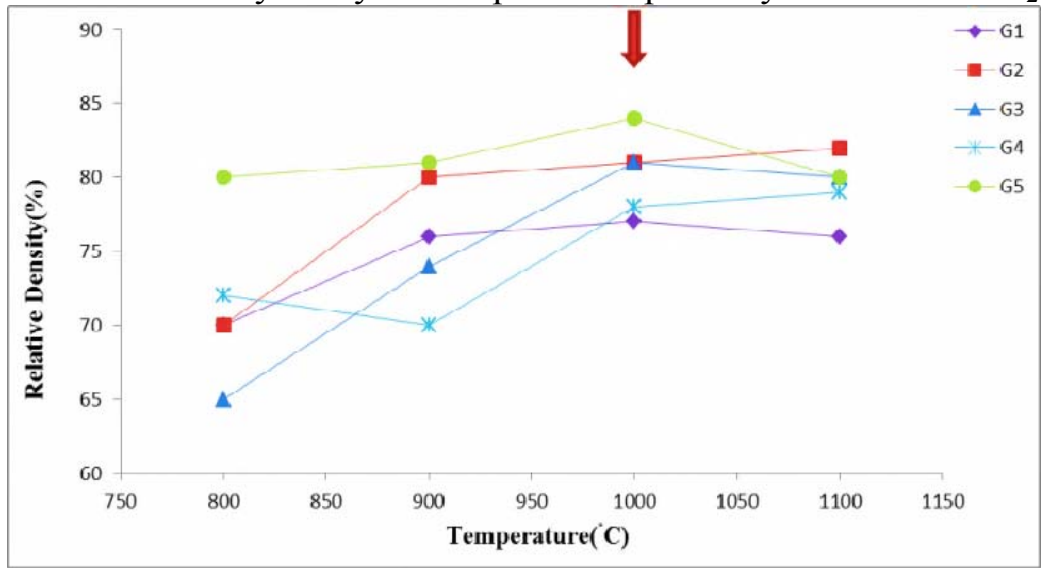

Fig. 3. Variation of relative density of glasses with firing temperature

As discussed beforehand, the most sinterability was observed in samples containing $\mathrm{TiO}_{2}$, which its relative density variation with temperature has been shown in Fig. 3. It is observed that the maximum density of samples were about $1000^{\circ} \mathrm{C}$. With comparison of sintering results and crystallisation peak temperature of each glass, it can be concluded that the maximum temperature, which leads to full density, is always more than crystallisation peak temperature of the glasses. This indicates that complete densification occurred through viscous flow of the residual glass. The presence of rigid particles of $\mathrm{TiO}_{2}$ and $\mathrm{ZrO}_{2}$ in the LSCA glass material probably reduces the mobility of the LCSA grain boundaries during the sintering process and prevents full densification.

\section{Crystallisation characteristics}

Crystallisation of $\mathrm{Li}_{2} \mathrm{O}-\mathrm{CaO}-\mathrm{SiO}_{2}$ glass-ceramics in traditional processes is generally achieved using small additions of oxides, particularly $\mathrm{TiO}_{2}[20-22], \mathrm{ZrO}_{2}$ [23,24], or a combination of both $[25,26]$ to the base glass. In the present work, it was found that the $\mathrm{Li}_{2} \mathrm{O}-\mathrm{CaO}-\mathrm{SiO}_{2}$ system glass with $\mathrm{ZrO}_{2}$ and $\mathrm{TiO}_{2}$ had high crystallisation tendency upon heat-treatment. This may be explained by the phase separation of the lithia-silica glass that is caused by the incompatibility of $\mathrm{Li}_{2} \mathrm{O}$ with $\mathrm{SiO}_{2}$ [27-29]. The X-ray diffraction analysis of G1 (Table 3, Fig. 4), showed that wollastonite$\mathrm{CaSiO}_{3}$ was crystallized as a major phase together with zircon $\mathrm{ZrSiO}, \beta$-eucryptite $\mathrm{LiAlSiO}_{4}$, $\mathrm{Li}_{2} \mathrm{Al}_{2} \mathrm{Si}_{3} \mathrm{O}_{10}$ and zirconia $\mathrm{ZrO}_{2}$. The XRD analysis of $\mathrm{G} 3$ (Table 3, Fig. 4), showed that, wollastonite- $\mathrm{CaSiO}_{3}$ phase, with zircon $\mathrm{ZrSiO}_{4}, \beta$-eucryptite $\mathrm{LiAlSiO}_{4}$, zirconia $\mathrm{ZrO}_{2}$ and $\mathrm{TiO}_{2}$ (minor) phases were formed. It seems that according to the differential thermal analysis (DTA) of the present glass $(\mathrm{G} 3)$, the first exothermic peaks appeared at $815^{\circ} \mathrm{C}$ was attributed to the crystallisation of wollastonite phase and the second exothermic peak observed at higher temperature $\left(850^{\circ} \mathrm{C}\right)$ was attributed to the formation of zircon, $\beta$-eucryptite and zirconia as secondary crystalline phases. The XRD analysis of G5 (Table 3, Fig. 4), indicated also that in sample contained $\mathrm{CaTiO}\left(\mathrm{SiO}_{4}\right)$ was crystallized as a major phase together with lithium calcium silicate phase- $\mathrm{Li}_{2} \mathrm{Ca}_{3} \mathrm{Si}_{6} \mathrm{O}_{16}$, lithium disilicate- $\mathrm{Li}_{2} \mathrm{Si}_{2} \mathrm{O}_{5}, \beta$-eucryptite $\mathrm{LiAlSiO}_{4}$ and $\beta$-spodumene $\mathrm{LiAlSi}_{2} \mathrm{O}_{6}$ phases. The results of X-ray analysis of glass-ceramics are also tabulated in Table 3 . 
Table 3. Crystalline phases in various samples

\begin{tabular}{ll}
\hline Sample no. & Crystalline phases \\
\hline $\mathrm{G} 1$ & Wollastonite, zircon, $\beta$-eucryptite, zirconia, $\mathrm{Li}_{2} \mathrm{Al}_{2} \mathrm{Si}_{3} \mathrm{O}_{10}$ \\
\hline $\mathrm{G} 3$ & Wollastonite, zircon, $\beta$-eucryptite, $\mathrm{Li}_{2} \mathrm{Al}_{2} \mathrm{Si}_{3} \mathrm{O}_{10}, \mathrm{TiO}_{2}$ \\
\hline $\mathrm{G} 5$ & $\mathrm{CaTiO}\left(\mathrm{SiO}_{4}\right)$, lithium calcium silicate, lithium disilicate, \\
& $\beta$-eucryptite, $\beta$-spodumene \\
\hline
\end{tabular}

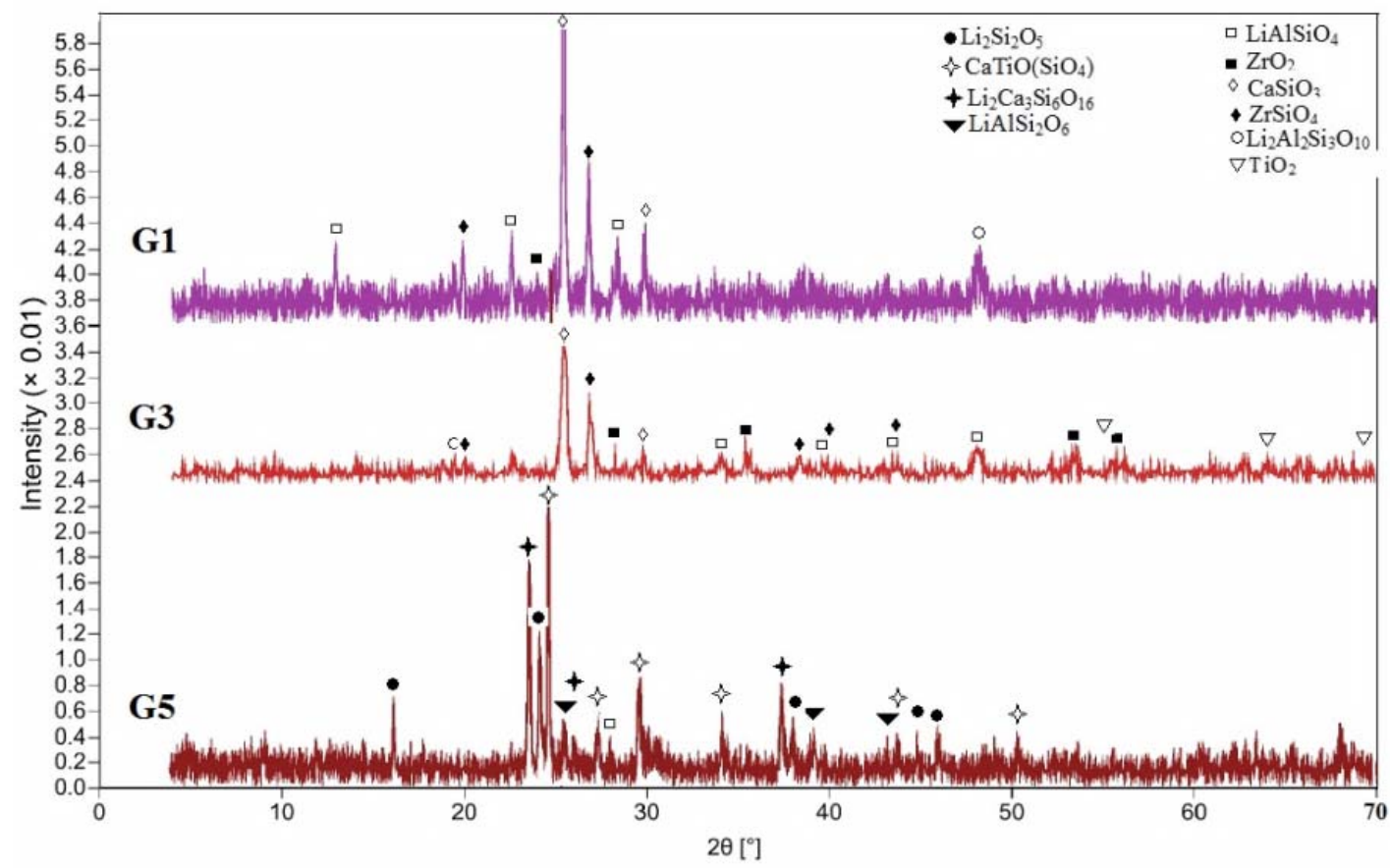

Fig.4. XRD patterns of glass-ceramics $\mathrm{G} 1, \mathrm{G} 3, \mathrm{G}$, after heat treatment at $1000^{\circ} \mathrm{C}$ for $4 \mathrm{~h}$

According to the XRD analysis, the nucleating agent $\mathrm{ZrO}_{2}$, as compared with $\mathrm{TiO}_{2}$, has a tendency to the transformation of quartz to wollastonite. In glasses containing $\mathrm{TiO}_{2}$, wollastonite crystals have not been formed.

\section{Microscopic examinations}

Fig.5 shows the micrographs of sample G1 after sintering taken by SEM at two different magnifications. These figures revealed zircon in wollastonite phase(rod-like morphologies). The line scanning analysis of zirconium is shown in Fig. 5(b). 

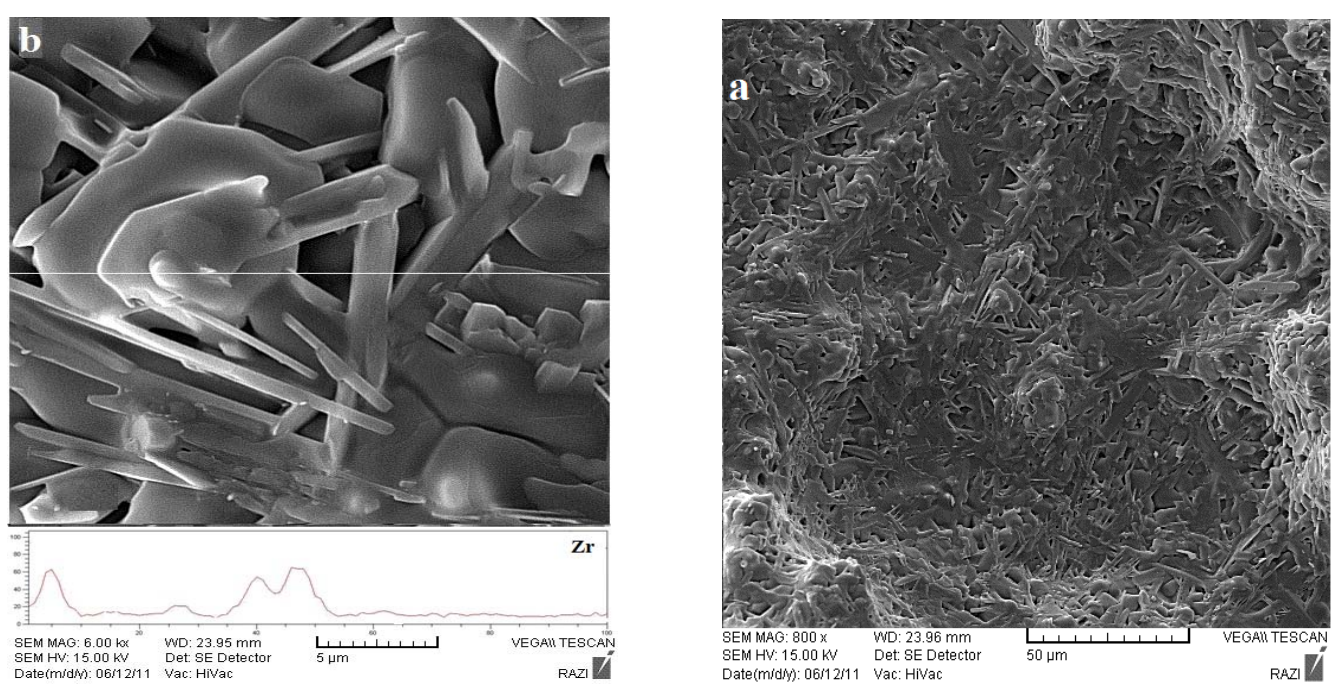

Fig. 5. SEM micrographs of crystallized G1: (a) magnification $\times 800$; (b) magnification $\times 6000$

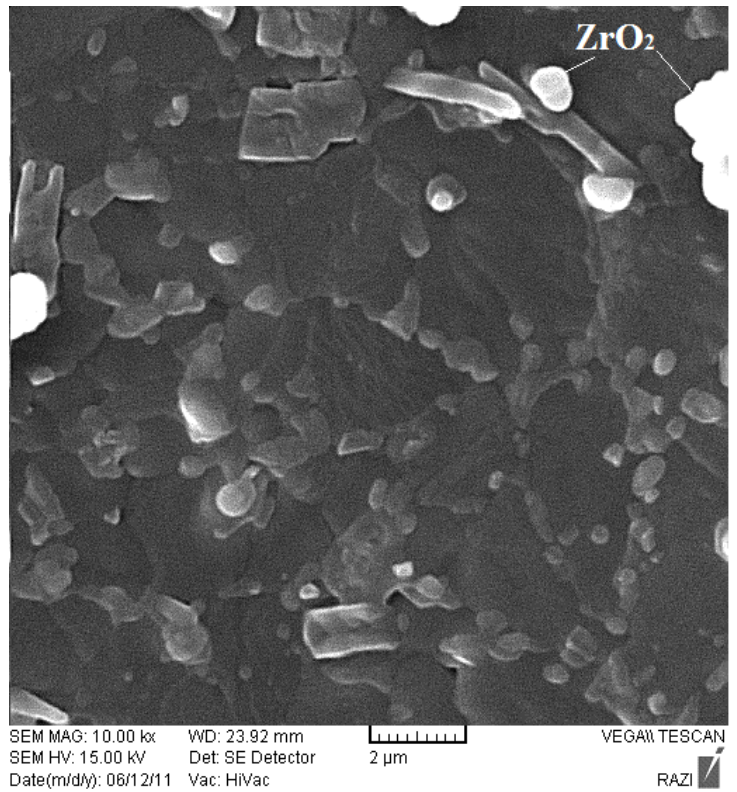

Fig. 6. SEM micrograph of $\mathrm{G} 3$, sintered at $1000^{\circ} \mathrm{C}$ for $4 \mathrm{~h}$

Zirconia phase was appeared in microstructure of G3 sample. The SEM micrograph in Fig. 6 indicates that the zirconia crystals are smaller than $2 \mu \mathrm{m}$. Fig. 7 shows EDX analysis of this phase. 


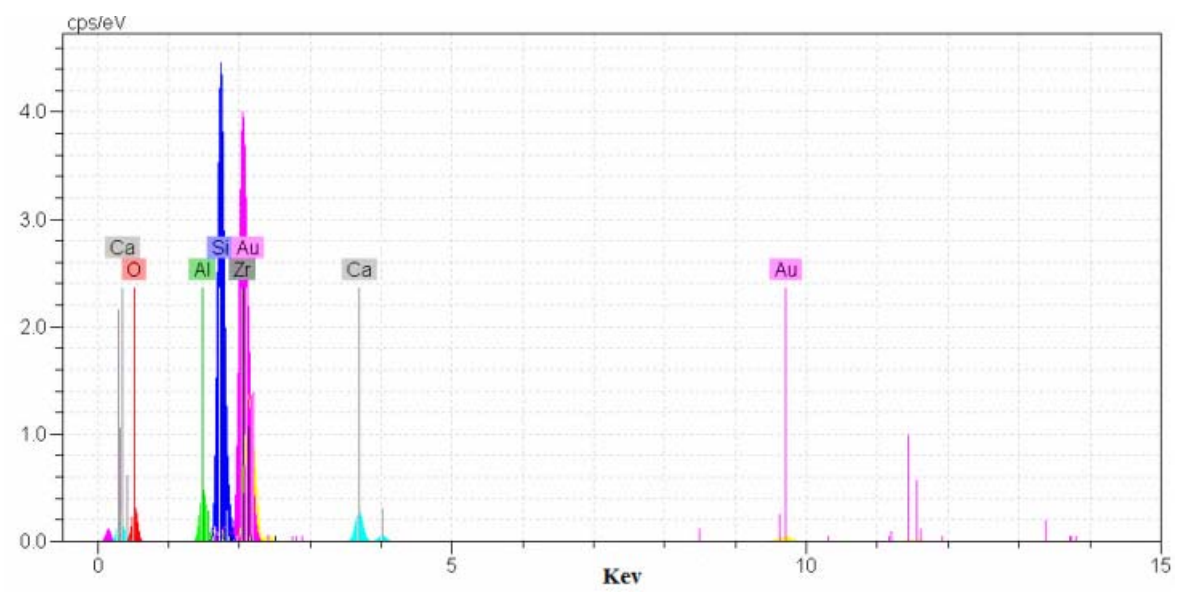

Fig. 7. $\mathrm{EDX}$ analysis of $\mathrm{G} 3$ sample of $\mathrm{ZrO}_{2}$ phase shown in figure 6
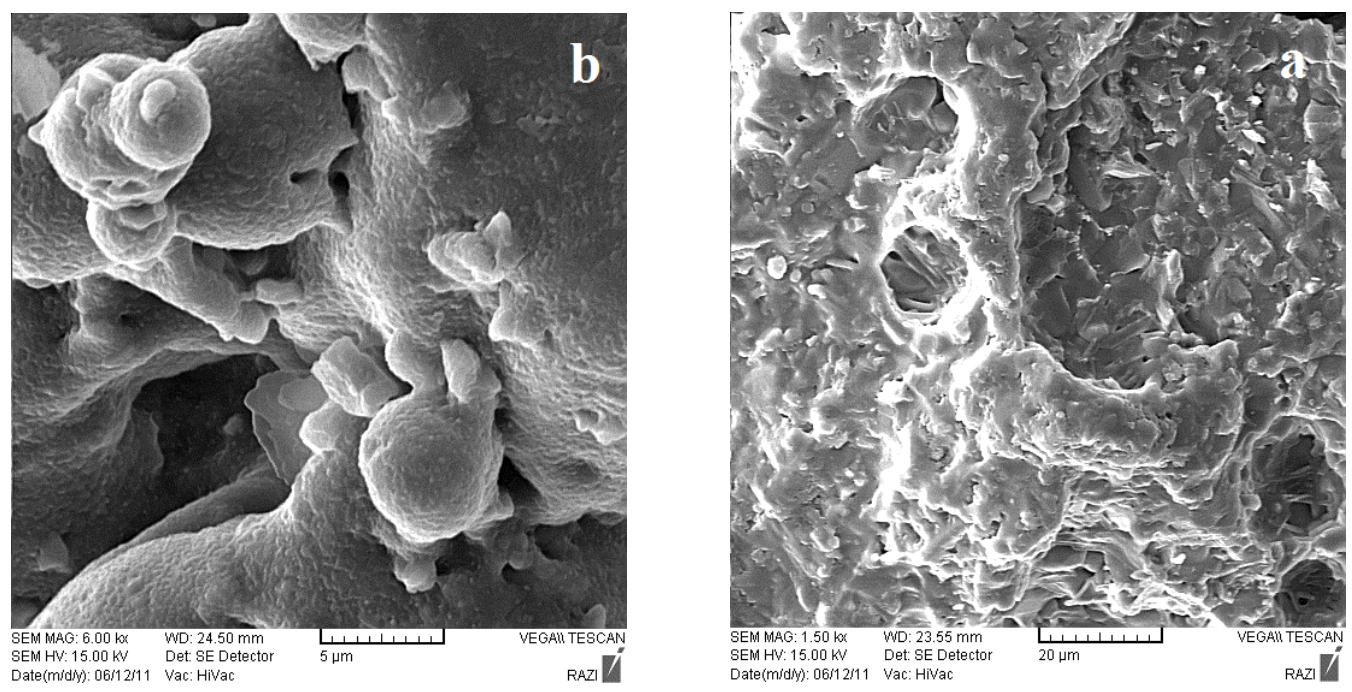

Fig. 8. Surface morphology of the SEM micrograph of G4 and G5, sintered at $1000^{\circ} \mathrm{C}$ for 4 h. (a) G4. (b) G5

Fig. 8(a) and (b) shows the SEM micrograph of the fracture surfaces of LCSA precursor added with $2.0 \mathrm{~mol} \%$ and $4.0 \mathrm{~mol}^{\circ} \mathrm{TiO}_{2}$, respectively, and sintered at $1000^{\circ} \mathrm{C}$ for $4 \mathrm{~h}$. The difference between Fig. 8(a) and (b) was due to the different $\mathrm{TiO}_{2}$ contents. It is obvious from Fig. 8(b) that the neck growth takes place between the contracting grains with a little particle coalescence. It was also seen from Fig. 8(a) that grain coalescence has occurred, but the remaining pore size is about $3.0 \mu \mathrm{m}$. It indicates that almost all pores are isolated. The relative density about $78.0 \%$ and $84 \%$ for compact LCSA samples contain $2.0 \mathrm{~mol} \%$ and $4.0 \% \mathrm{~mol} \%$, respectively, as sintering at $1000{ }^{\circ} \mathrm{C}$ for $4 \mathrm{~h}$. This result indicates that for adding $4.0 \% \mathrm{~mol} \mathrm{TiO}_{2}$ in the LCSA precursor incipient melting occurs; however, it does not contribute to the densification of the sintered body. Fig. 9 shows the variation of bending strength of the glass-ceramics with firing temperature. The bending strength of specimen increases continuously up to the optimum sintering temperature, i.e. $1000^{\circ} \mathrm{C}$. 


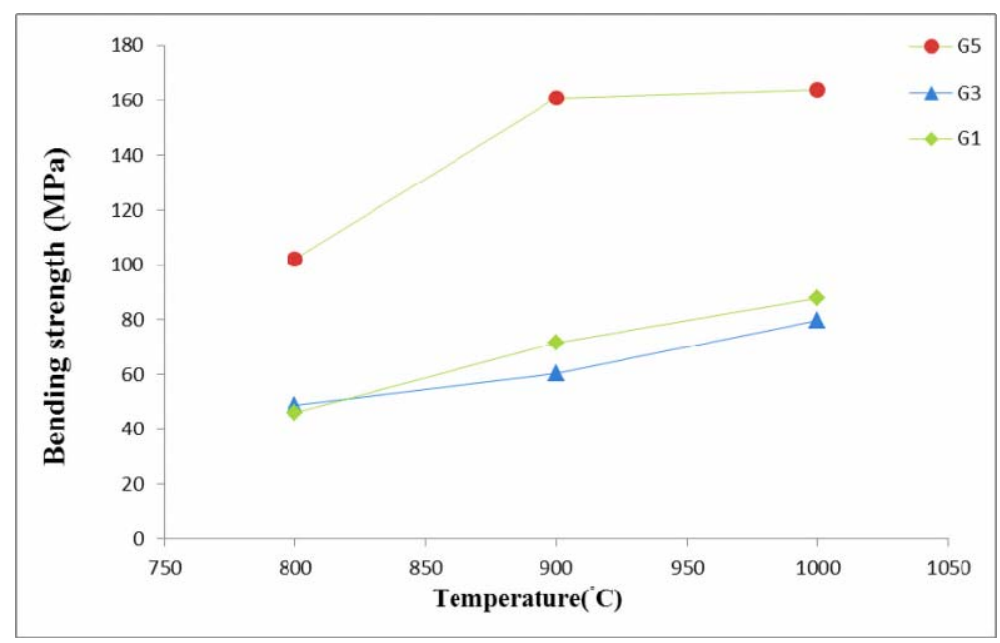

Fig. 9. Variations of bending strength versus temperature of sintering

Sample G5 at $1000^{\circ} \mathrm{C}$ has higher bending strength i.e. 164MPa. It seems that low density is responsible for lower bending strength of G1 and G3. There was rigid zirconia particle in microstructure of G1 and G3, however it contained more porosity, due to its poorer sinterability.

\section{CONCLUSIONS}

The sintering $\mathrm{Li}_{2} \mathrm{O}-\mathrm{CaO}-\mathrm{SiO}_{2}-\mathrm{Al}_{2} \mathrm{O}_{3}$ with $\mathrm{TiO}_{2}$ and $\mathrm{ZrO}_{2}$ additives have been investigated. The results in this study are summarized as follows:

1. Addition of $\mathrm{TiO}_{2}$ to glasses, shifts the glass transision and the crystallisation peak to lower temperature and improve sinterability.

2. Sample contained $\mathrm{TiO}_{2}$ and free of $\mathrm{ZrO}_{2}$ has maximum shrinkage and excellent sinterability.

3. The presence of rigid particle of $\mathrm{ZrO}_{2}$ in the LSCA glass material reduces the mobility of the LSCA grain boundaries during the sintering process and prevents full densification at $1000^{\circ} \mathrm{C}$.

4. The increase of the sintering temperature to $1000^{\circ} \mathrm{C}$ reduce the porosity of the $\mathrm{ZrO}_{2}-\mathrm{LCSA}$ glass ceramic material, but not to the adequate porosity level as observe for the $\mathrm{TiO}_{2}-\mathrm{LCSA}$ material.

5. For the samples of the LCAS precursor powders added with various amounts of $\mathrm{ZrO}_{2}$ and $\mathrm{TiO}_{2}$ sintered at $1000^{\circ} \mathrm{C}$ for $4 \mathrm{~h}$, the crystallized phases is found to be mostly wollastonite plus a minor phase of zirconia for $\mathrm{ZrO}_{2}$ agents and mostly $\mathrm{CaTiO}\left(\mathrm{SiO}_{4}\right)$ for $\mathrm{TiO}_{2}$.

6. The presence of $\mathrm{ZrO}_{2}$ and $\mathrm{TiO}_{2}$ shows a different behavior. The addition of $\mathrm{TiO}_{2}$ improves the mechanical behavior of the LCSA glass material at $1000{ }^{\circ} \mathrm{C}$, but the incorporation of $\mathrm{ZrO}_{2}$ decreases the strength values. 


\section{ACKNOWLEDGMENTS}

The authors are indebted to ceramic laboratory in instituted of standard and research industrial of Iran, that supplied the raw materials for the development of this research and to ceramic department (International University of Iran) for its financial support.

\section{REFERENCES}

1. Strand Z.: Glass Ceramic Materials, Glass Science and Technology, vol. 8, Elsevier, Amsterdam, 1986.

2. $\quad$ Beall G.H., Duke D.A.: Transparent glass- ceramics. Mater. Sci 4 (1969) 340.

3. Alizadeh P., Marghussian V.K.: The effect of compositional changes on the crystallisation behavior and mechanical properties of diopside-wollastonite glass-ceramics in the $\mathrm{SiO}_{2}-\mathrm{CaO}-\mathrm{MgO}\left(\mathrm{Na}_{2} \mathrm{O}\right)$ system. European Ceramic Society 20 (2000) 765-773.

4. Chaim R., Talanker V.: Microstructure and mechanical properties of SiC platelet/cordierite glass ceramic composites. American Ceramic Society 78 (1995) 166-172.

5. Acchar W., Martinelli A.E., Cairo C.A.A.: Reinforcing $\mathrm{Al}_{2} \mathrm{O}_{3}$ with W-Ti mixed carbides. Materials Letter 46(2000) 209-211.

6. Acchar W., Martinelli A.E., Cairo C.A.A.: Sintering behavior of alumina-tungsten carbide. Materials Science and Engineering 284 (2000) 84-87.

7. Acchar W., Martinelli A.E., Cairo C.A.A., Bressiani A.H.A.: Sintering behavior of alumina-niobium carbide composites. European Ceramic Society 20 (2000) 1765-1769.

8. Pasotti R.M.R., Bressiani A.H.A., Bressiani J.C.: Sintering of alumina-niobium carbide composites. International Journal of Refractory Metals \& Hard Materials 16 (1998) 423-427.

9. Tai W.P., Watanabe T.: Fabrication and mechanical properties of $\mathrm{Al}_{2} \mathrm{O}_{3}-\mathrm{WC}$ composites by vacuum hot-pressing. American Ceramic Society 81 (1998)1673-76.

10. Acchar W., Cairo C.A.A., Segadaes A.M.: Effect of tungsten carbide additions on the microstructure and properties of hot-pressed alumina. Materials Science \& Engineering 406 (2005) 74-77.

11. Acchar W., Fonseca J.L.: Sintering behavior of alumina reinforced with (Ti,W) carbides, Materials Science \& Engineering 371 (2004) 382-387.

12. Accahar W., Schwarze D., Greil P.: Sintering of $\mathrm{Al}_{2} \mathrm{O}_{3}-\mathrm{NbC}$ composites using $\mathrm{TiO}_{2}$ and $\mathrm{MnO}$ additives", Materials Science \& Engineering 351 (2003) 299-303.

13. James P.F.: Glass-ceramic:newcompositionsanduses. Non-Cryst.Solids181(1995)1-15.

14. Riello P., Canton P., Comelato N., Polizi S., Verita M.,G., Fagherazzi H.: Nucleation and crystallisation behavior of glass-ceramic material in the $\mathrm{Li}_{2} \mathrm{O}-\mathrm{Al}_{2} \mathrm{O}_{3}-\mathrm{SiO}_{2}$ system of interest for their transparency properties. Non-Cryst.Solids 288(2001)127-139.

15. Cheng K.: Determining crystallisation kinetic parameters of $\mathrm{Li}_{2} \mathrm{O}-\mathrm{Al}_{2} \mathrm{O}_{3}-\mathrm{SiO}_{2}$ glass from derivative differential thermal analysis curves. Mater.Sci.Eng 60 (1999)194-199. 
16. Tick P.A., Borrelli N.F., Reaney I.M.: Relationship between structure and transparency in glassceramic materials. Opt.Mater 15 (2000) 81-91.

17. Beall G.H., Kreadl D.A., in: D.R. Uhlmann, N.M. Kreadl (Eds.), Glass Science and Technology, Vol. 1, Academic Press, New York, 1983, pp. 403-445.

18. Duan R.G., Liang K.M., Gu S.R.: Effect of changing $\mathrm{TiO}_{2}$ content on structure and crystallisation of $\mathrm{CaO}-\mathrm{Al}_{2} \mathrm{O}_{3}-\mathrm{SiO}_{2}$ system glasses. Eur. Ceram. Soc 18 (1998) 1729-1735.

19. Morimoto S., Kuriyama N.: Effect of $\mathrm{TiO}_{2}, \mathrm{ZrO}_{2}$ and $\mathrm{P}_{2} \mathrm{O}_{5}$ on the crystallisation of $\mathrm{SiO}_{2}-\mathrm{Al}_{2} \mathrm{O}_{3}-$ $\mathrm{MgO}-\mathrm{CaO}-\mathrm{Na}_{2} \mathrm{O}$ glass system. Ceramic Society of Japan 104 (1996) 442-443.

20. Barry T.I., Clinton D., Lay L.L., Mercer R.A., Miller R.P.: J. Mater. Sci. 5 (1970) 117-126.

21. Stookey S.D., US Patent 2,920,971 (January 12, 1960).

22. Doherty P.E., Lee D.W., Davis R.S.: Direct Observation of the Crystallisation of $\mathrm{Li}_{2} \mathrm{O}-\mathrm{Al}_{2} \mathrm{O}_{3}-\mathrm{SiO}_{2}$ Glasses Containing $\mathrm{TiO}_{2}$.American Ceramic Society 50 (1967) 77-81.

23. Acchar W.I., Torquato W.L., Sousa C.R.C.: Using $\mathrm{ZrO}_{2}$ or $\mathrm{Al}_{2} \mathrm{O}_{3}$ particles to enhance the mechanical properties of a LZSA glass-ceramic matrix. Revista Matéria 14(2009) 674 - 679.

24. Sack V.W., Scheidler H.: Glasstech 39 (1966) 126-130.

25. Wang M.C., Yang S., Wen S.B., Wu N.C.: Sintering $\mathrm{Li}_{2} \mathrm{O}-\mathrm{Al}_{2} \mathrm{O}_{3}-4 \mathrm{SiO}_{2}$ precursor powders with ultrafine $\mathrm{TiO}_{2}$ additives. Materials Chemistry and Physics 76 (2002) 162-170.

26. Stewart D.R., in: Hench L.L., Freeman S.W. (Eds.).: Advances in Nucleation and Crystallisation in Glass. American Ceramic Society, Columbus, OH, 1971, pp. 83-90.

27. McMillan P.W.: Glass-ceramics, Academic Press, London, NY, 1979.

28. Strnad Z.: Glass-ceramic materials Glass Science and Technology, vol. 8, Elsevier, Amsterdam, 1986.

29. Shelby J.E., Shelby S.R.: Phase separation and the properties of lithium calcium silicate glasses. Phys. Chem. Glasses 41 (2) (2000) 59-64. 